\title{
Review Work on Productive and Reproductive Performance of Crossbreed Dairy Cattle in Ethiopia
}

\author{
Brhane Gebremariam \\ College of Agriculture and Natural Resources, Raya University, Ethiopia
}

\begin{abstract}
Ethiopia enowed with alarge livestock population in africa as well as in the world. Dairy farming is one of the world wide practiced farming including Ethiopia. The main aim of this review is to know the overall preformance (both productive and reproductive) of crossbred dairy cattle in Ethiopia. According to inputs, agroecology, intensity of production dairy farming is catagoized as low land pastoralism, high land smallholder, urban and peri-urban small scale dairy farm and intensive (specialised comercial) dairy farming systems. The feed resourse for low land pastoralism and highland small holders is mostly natural pastures and crop by products. However, for urban and peri-urban small scale and intensive farms is purchased hay, green legum and other concentrats. Ethiopia has divrrsified dairy cattle breeds and the cross breeds have different production performance. Those differences in performance with in and between breeds could be due to management activity. There are also constraints that can influence the performance of dairy cattle like shortage of feed, poor genetic performance and poor management systems. The existing opportunities to improve thire performance includes the presence of diversified breeds as well as introducing of artificial insemination service technology. Besides these, the productive and reoroductive performance can be improve through good management. Therefore, good forage development strategy and good breeding strategies must be under taken by the government as well as other concerned bodies.
\end{abstract}

Keywords: Productive, Reproductive, Preformanec, Dairy Cattle, Management

DOI: $10.7176 / \mathrm{JBAH} / 9-6-04$

Publication date:March $31^{\text {st }} 2019$

\section{INTRODUCTION}

Ethiopia is rich in livestock population and owes 52.13 million head of cattle which makes largest population in Africa [1]. Despite this fact the farming system is subsistent where there is no specialized and systematic breeding used. One of the main uses of livestock is for milk production. The annual milk production in Ethiopia is 1.5 million tons and showed increment of $1.55 \%$ rate from year 1961 to 2000 periods [2]. However, their production and reproduction potential is seriously limited due to genetic and poor management factors. Consequently, the supply of milk is lagging behind the demand of over increasing human populations. Genetic improvement through cross breeding of indigenous stock with exotic dairy types, reputable in dairy characteristic has been recommended as an alternative to increase the production and reproduction performance of dairy cow in many tropical countries including Ethiopia [3].

The country has made a great effort to improve the productivity and reproductively of local breeds through artificial insemination program to cross breed of locally adapted to improved exotic dairy cattle [4]. Good productive and reproductive performance and longer herd life are the effect of up grading through crossbreeding [5]. In Ethiopia crossbreeding activities have been used to improve performances of local cattle [6]. In spite of such practical efforts their performance is still kept low and limited [5]. Hence, this review focuses to see the performances (both productive and reproductive) of crossbred dairy cattle in Ethiopia.

\section{PRODUCTIVE AND REPRODUCTIVE PERFORMANCE OF CROSSBREED DAIRY CATTLE IN ETHIOPIA}

Production system

Lowland pastoralist

This production system is practiced in pastoral range lands where it is further classified in to pastoral and agropastoral. In agro-pastoral areas crop production were carried out beside to livestock production activities. However, in pastoral ones only livestock and livestock products where used. In both pastoral and agro-pastoral the main product produced as food is milk [7].

\section{Highland small- holder}

There are two types systems in the highland. The traditional system that is based on indigenous breeds and the market oriented system that is based on crossbreed dairy cattle. The milk produced is mainly consumed by the household in the traditional system while most of the milk is sold to generate income in the market oriented system [8]. 


\section{Small scale}

Small scale dairy farming is practiced around towns and cities. This production system is characterized by use of agro-industrial products and purchased roughage feeds. The agro-industrial products are supplemented for animas which based on grazing pasture and crop- residue. Therefore, giving due attention by government policies will make this sector developed. These are medium sized dairy farms that own crossbred dairy cows. Farmers use all or part of their land for forage production [9].

\section{Commercial}

This farming system is found in major cities like Addis dairy Ababa and range from small to a large scale farms. In here, there is specialization in farming of cattle based on production and breeding objectives. These dairy farms mainly established for production of milk for market and use improved cattle (exotic and crossbred) for its realization [7].

\section{Management \\ Feed resource and feeding system}

Type of feed sources and feeding system has its own impact on dairy cattle production and performances. Considering development strategies to cope with the short falls, development of feed conservation measures and strategic supplementation for milk production has shown great influences [10]. However, still there is no adequate feed and forage resources development strategies and practices. The feeding systems is highly dependent on roughage feed resources like crop residues, natural pastures and crop aftermath [11].

\section{Water sources and watering system}

In low land smallholder production system, dairy cattle gets water from river and water holes but in urban, peri urban and commercial farms they get from pipe water. Performance and/or breed of the animals and type of predominant feed (dry or wet) and feeding systems (indoor or out-door) affects water requirement of the animals. In small scale farming around $36 \%$ of farmers/dairy cattle producers provide water with a frequency of one's a day but $64 \%$ of households provide water for their cattle more than two times a day and in commercial farms dairy cattle get it free [11].

\section{Health management}

Health care is one of the management aspects of dairy cattle production. To improve the production, dairy cattle should be kept healthy. There are several dairy cattle disease affecting the performance of the animals like mastitis, calf scours and reproductive disease [12]. The major disease in Addis Ababa is considered to be mastitis and lumpy skin disease. Moreover, in small and large scale commercial dairy farms there is high incidence of sub-clinical and clinical mastitis which goes from 25 to $95 \%$ [13].

\section{Manure handling}

There is variation in manure handling amongst the production systems. Manure handling is very important to take advantage of fertilizers [11]. Manures like urine, waste water, feed left overs are removed manually, through machinery and use of concrete drainage [14]. If not properly managed, manure is a source of bad odor and flies and sources of zoonotic diseases. Dairy producers from urban dairy system complained that manure disposal incurs cost. Although urban dairy farming is recognized by public authorities in some urban center, it was not encouraged in others and so there is a lot of pressures and restriction on dairy producers [15]. In most situations, the systems for manure management and use are very serious problems to both animals and human beings. In specialized farming, manure is used to generate energy in the form of biogas.

\section{Housing}

Provision of house for dairy animals is very vital. It reduces sever climatic influences (extreme heat, cold and dusty wind) and brings comfort for the animals. Stress and other related problems could be avoided by good housing. It helps to control the environment and reduce diseases, hazards and make the management better. Through this production could be determined. Several criteria's are set to select an area for dairy farming like fertility of land, absence of drainage, access to facilities like transportation to collecting center, access to supplies for farming, clean and sufficient water all year and distance from factories or other farms which may release bad odor or lead to pathogenic infections [16]. The type of house provided for dairy animals varied with agroecology, physiological stage of the animal and production systems [11].

\section{Productive performance \\ Milk yield}

Milk yield and lactation length are the determinants of lactation performances. In smallholder cross breed dairy 
cattle of tropical countries it ranges from 6.5 to $9.8 \mathrm{Litter} /$ day [17]. Contributing factors for variation in lactation performances from season to season/year to year is due to herd size, good management and age of the animal [18].

\section{Lactation length}

It is a period/time a cow continues giving milk from date of calf delivery/ parturition [19]. Lactation length of crossbred of different indigenes cows with Holstein Frisian/HF like Arsi XHF of 50\%, 75\% and 87.5\% have lactation length of 334, 408 and 411 days respectively and crossbred of Zebu X HF of 50\%, 75\% and $87.5 \%$ have lactation length of 378, 378 and 411 days respectively [20]. Crossbred of Borana X HF of 50\%, $75 \%$ and $87.5 \%$ have lactation length of 337,351 and 355 days respectively [21].

\section{Reproductive performance Age at first calving}

This is a time where heifers deliver/give birth to a calf for the first time. This indicate the beginning of cows a productive life. Body condition is an important variable that indicating the reproductive status and the expected performance of a cows [22]. Early sexual maturity and young AFC is very much perceived in light of increasing the total productive and economic efficiency [23]. AFC is important to decrease the unproductive period of cow's life and to reduce the generation interval in response to selection favorably [24]. The average age at first calving of cross breed dairy cattle in Ethiopia especially in Amhara region was 37.95 months and 44.5 months. This is due to accessibility in artificial insemination utilization, better heat detection and awareness [25].

\section{Days open}

Days open (Do) is the period from date of parturition to the subsequent date of successful conception. Days open affects life time production and would also tend to increase the generation interval there by causing a decrease in the annual genetic gain [26]. The average day open for cross breed dairy cow in Ethiopia is 85.6 days [27].

\section{Calving interval}

This is the time between two successive birth and measures cattle herds' reproductive efficiency [6]. Short calving intervals are of great advantage because attaining short calving interval enables to exploit the early peak yields of each lactation [28]. Improving manage mental practices enhance reproductive performances like shortening calving intervals. The average calving interval of cross breed dairy cow in Ethiopia especially in Amhara was shorter than 17.8 month [29].

\section{Service per conception}

Number of service per conception is the number of service; be its natural or artificial required for successful conception. The number of insemination required to produce alive calf is one of the most useful parameters for measurement of reproductive efficiency [13]. The idea number of service per conception required for well managed herd ranges from 1.3 to 1.6. this depends on overall management and breeding activities [22]. Uncontrolled natural mating shows higher service per conception than artificial ones. If the service per conception in a given farm is above two, it is considered as poor [6]. However, in the majority of the poorly managed herd's average of two (2) or more NSC are required [22].

\section{Constraints and opportunities Constraints \\ Shortage of feed}

Feed is the major cost of a given dairy farm. Dairy producers reported that animal feed cost increases regularly and there is limited access to feeds and these are major problems that hamper dairying in cities. The constraints of livestock production can be categorized as natural and man-made factors. These factors also relate to each other [30]. Feed scarcity is one of a great challenge and constrains the livestock sector. Feed availability varies with season and sustainable feed conservation and development is still a limit [11]. Moreover, in Ethiopia there is high population growth and land scarcity which adds a fuel to the feed shortage for livestock [31]. Crop livestock production systems have a better chance to supplement for livestock using crop residue and other farm by products.

\section{Disease}

One of the major constraints and highly affecting dairy cattle performances like reproduction and milk productions is disease. A number of parasite, bacterial, fungal and viral diseases and nutritional deficiency which 
are prevalent in the country affect the productivity and reproductive efficiency of dairy cattle [32]. Farm management and dairy efficiency are not always available in the dairy farmer. In dairy cattle productions the major commonly seen disease problems are mastitis and foot and mouth disease. Moreover, disease like trypanosomiasis, schistosomiasis, fasciolasis, gastro-intestinal tract parasites, pasteurolosis, lumpy skin disease, anthrax, malignant fever, tuberculosis, black leg and trypanosomosis and lung worm are also observed. However the prevalence varies with different factors which are management and agro-ecology [1].

\section{Poor -management}

Dairy cattle performance is influenced by several factors like management, lactation length, age, season and nutrition. There are also other constraints including lack of capital, water problems related to waste disposal and poor animal health services which are common dairying constraints reported for urban and peri-urban producers [33].The reason for variation in performance could be due to effect of feed, health, management aspect and genotype. Moreover, a good housing is necessary to ensures better environmental situation. Space for waste disposal as well as lack of sufficient land for proper housing, milking and farm expansion has been considered as constraint to produce good quality milk [18].

\section{Opportunities}

Inputs

Information on dairy farming is a necessary condition for its successful establishment. The information are obtained from family, personal experience, governmental and non-governmental organizations, radio etc. Beside to provision of the information, governments afford inputs like feed stuffs (wheat bran and molasses), educations (formal and informal) and health extensions (vaccine and treatments). This creates suitable condition for better breed improvements through appropriate breeding techniques [11].

\section{Introducing of artificial insemination service}

Artificial insemination is very important for genetic improvement of local animals and avoids disease transmission. The numbers of artificial insemination service centers has been increasing and cover most urban and per-urban areas and some parts of rural highlands [34].

\section{CONCLUSIONS AND RECOMMENDATIONS}

Considering several factors like climate condition, land availability, crop production, market access, production intensity as well as agro-ecologies; four major dairy farming are distinguished in the country as lowland pastoralist, highland smallholder, urban and peri-urban small scale and commercial farming. The feed resources for low land pastoralism and high land small holders are mostly natural pastures and crop residues. However, for urban and peri urban small scale and intensive farms is purchased hay, green legume and other concentrates. Productive and reproductive performance of dairy cattle mainly depends on breed type. Crossbreed dairy cattle are more productive than our indigenous breeds. They are known for their lower age at puberty, high fertility rate, and better lactation length and body weight. However, thus performances are affected by management systems. The main constraints of dairy cattle production includes, feed shortage, poor potential of local cows, disease prevalence, low management system, lack of reproduction and breeding management. Even though the constraints negatively influence the production, the existing genetic diversity in the country, availability of agroindustrial by products, focus given by the government are important opportunities used for the development of the performance of dairy cattle production. Therefore, to improve the performance of crossbred dairy cattle it is necessary to improvement the overall management system and alleviate the constraints which hinders the progress of the dairy sector. Opportunities should also be wisely used to exploit the best potential.

\section{ACKNOWLEDGEMENTS}

I am grateful to Raya University for providing internet access. I am also indebted to all my colleagues who devoted their time, energy and their resources for sharing vital comments and suggestions.

\section{REFERENCES}

1. CSA (Central Statistics Agency) (2015) Agricultural sample survey report on livestock and livestock characteristics (private peasant holdings). Volume II, Statistical bulletin, 578, Addis Ababa, Ethiopia.

2. FAO (Food and agriculture organization of united nation) (2005) Agricultural data base system.

3. Belete A, Azage T, Fikadu B and Birhanu J (2010) Cattle milk and meat production and marketing system in Ethiopia.

4. Gizachow A, Bekan M and Regassa F (2005) Reproductive performance of cross breed dairy cattle in tropical animal healthy and production. PP $373-379$.

5. Sintayew G (2000) Characterization of dairy productive and reproductive in Ethiopia. Addis Ababa, 
Ethiopia p 15-21

6. Mukessa. M (2000) Reviews of reproductive performance of animal Boss indicus cattle monograph 6. ILC, Addis Ababa, Ethiopia.

7. IBC (Institute of Biodiversity Conservation) (2004) The state of Ethiopia's farm animal genetic resources: A contribution to the first report on the state of the world's animal genetic resources. Addis Ababa, Ethiopia.

8. Tadesse M, Thiengtham J, Pinyopummin A, Prasanpanich S (2016) Productive and reproductive performance of Holstein Friesian dairy cows in Ethiopia. Livestock Research for Rural Development 22 (2):21.

9. Azage T, Tsehay R, Alemu G, Hizkias K (2000) Milk recording and herd registration in Ethiopia. In Proceedings of the 8 Annual Conference of the Ethiopian.

10. ILRI (International Livestock Research Institute) (1995) Livestock development strategies for low-income countries. Proceedings of the joint ILRI/FAO round table on livestock development strategies for low income countries. Addis Ababa, Ethiopia.

11. Azage T, Berhanu G, Hoekstra D, Berhanu B, Yoseph M (2013) Smallholder dairy production and marketing systems in Ethiopia: IPMS experiences and opportunities for market-oriented development. IPMS (Improving Productivity and Market Success) of Ethiopian Farmers Project Working Paper 31. Nairobi: Kenya. 65p.

12. Dessalegn, G (2015) Assessment of production and reproductive performances of cattle and husbandry practices in Bench-Maji Zone, South west Ethiopia. Global Journal of Animal Scientific Research. 3(2):441452.

13. Shiferaw Y, Tegegn BA, Bekana M, Kasa T (2003) Reproductive performance of cross breed dairy cows in different production systems in central highland of Ethiopia. Tropical Animal Health and Production. p25, $551-561$

14. Yoseph M, Azage T, Alemu Y (2003) Evaluation of the general farm characteristics and dairy herd structure in urban and peri-urban dairy production systems in Addis Ababa Milk Shed. Addis Ababa, Ethiopia, 139-144.

15. Anteneh A (2010) The role and performance of livestock in Ethiopia. In the $3^{\text {rd }}$ national live stock improvement conference. Addis Ababa, Ethiopia.

16. Tsegay L, Agengew A, Ashenafi S (2015) Dairy cattle production at small holder level in Sidama Zone selected districts, Southern Ethiopia. Food Science and Quality Management (IISTE).40: 7

17. Msanga YN, Bryant MJ (2003) Effect of restricted suckling of calves on the productivity of crossbred dairy cattle. Tropical Animal Health and Production 35, 69-78.

18. Mohamed N, Bouallegue M, Froujas R, Brars K, Hamouda MB (2012) Effects of environmental factor on milk yield, lactation length and dry period in Tunisian Holsteins cow. Available at http://dx.doi,org/10.5772/50803

19. Gebrekidan TW, Zeleke MZ, Gangwar SK (2012. Reproductive and productive performance of dairy cattle in central Zone of Tigray, northern Ethiopia. International Journal of Advanced Biological Research, 2(1):58-63

20. Gabriel HK, John CM, Trail MY, Kurtu GW, Frank MA, Jeffrey D (1983) Crossbred dairy cattle productivity in Arsi Region, Ethiopia. ILCA Research Report No. 11.

21. Aynalem H, Workneh A, Noah K, Tadelle D, Azage T (2011) Breeding strategy to improve Ethiopian Boran cattle for meat and milk production. IPMS (Improving Productivity and Market Success) of Ethiopian Farmers Project Working Paper 26. Nairobi, Kenya

22. MC. Dowell RE (2003) Improvement of livestock production in warn climate. W H. Freeman and company, Sanfrancisco, USA. World animal evolution 38 p31-36.

23. Singh K, Khanna AS, Kanauji AS (2001) Factor effecting lactation performance and persistency in crossbreed cattle. Indian Journal of Dairy Science 53 (5): 354-360.

24. ILRI (International Livestock Research Institute) (2005) International livestock center for Africa live stock research manual, ILCA, Addis Ababa, Ethiopia part I, 287P.

25. Mulugeta A (2005) Characteristics of dairy production systems of yarer watershed Adalibeb woreda, Oromia origin, Ethiopia. MSc. Thesis. Dire Dawa, Ethiopia.

26. Marrow DA, Roberts SJ, Etofeek MC (2012) Postmortem ovarian activity and involution of the uterus and cervix in dairy cattle.

27. Negussie E, Brannang E, Benjaw K, Rottmann OU (2003) Reproductive performance of local and cross breed dairy cattle at Asela livestock farm, Arsis, Ethiopia. p15-17.

28. Melaku N (2001) Reproductive performance of Holstein Friesian dairy cattle herd at Holeta, Shoa, Ethiopia. p2

29. Weldeslasse GT, Zeleke ZM, Gangwar SK (2012) Reproductive and productive performance of dairy cattle in Central Zone of Tigray, Northern Ethiopia. International Journal of Advanced Biological Research 2 
(1):58-63.

30. Tesfaye A, Chilot Y, Mengistu A, Elias Z, Aster Y (2002) Smallholder livestock production systems and constraints in the highlands of North and West Shewa Zones. In: Proc. of $9^{\text {th }}$ annual conference of the Ethiopian Society of Animal Production (ESAP), Addis Ababa, Ethiopia, pp: 49-72.

31. Fetsum S, Solomon Z, Mikias D, Yigremachew S, Demeke M, Gizachew W, Yeshi C (2009) Gender based participatory rural appraisal of farming systems in Wombera, Bullen and Guba Woredas. Addis Ababa, Ethiopia, pp: 161-187.

32. Mureda E, Zeleke MZ (2008) Characteristics and constraints of crossbred dairy cattle production in lowland areas of Eastern Ethiopia. Livestock research for rural development, V.20.

33. Sintayehu Y, Fekadu B, Azage T, Berhanu G (2008) Dairy production, processing and marketing systems of Shashemene-Dilla area, Southern Ethiopia.

34. Desalegn G, Merga B, Azage T, Kelay B (2009) Status of artificial insemination service Ethiopia. A paper presented at the $17^{\text {th }}$ Annual Conference of the Ethiopian Society of Animal Production (ESAP), September, 2009, held at the Ethiopian Institute of Agricultural Research (EIAR), Addis Ababa, Ethiopia. Pp. 87-104. 